\title{
Sociocultural Adjustment of Foreign Students in the Philippines
}

\author{
Maricel C. San Diego ${ }^{1}$ \\ ${ }^{1}$ College of Education Bulacan State University, City of Malolos Bulacan, Philippines, 3000 \\ 1 권(호)_8_fin
}

\begin{abstract}
Background/Objectives: Due to the perpetual rise of English as second language programs in the Philippines, it is vital to determine the sociocultural adjustments of international students throughout their academic stay. Methods/Statistical analysis: The researcher conducted an interview and adopted the questionnaire of Li (2010) to gauge their sociocultural adjustments in terms of their behavior and cognitive ability. Through the InputProcess-Output model, the gathered data were treated through tabulating the frequency, percentage, and mean. After the assessment, the researcher found out that foreign students experience slight difficulty in coping up with behavior and cognitive adjustments brought by a new culture and environment. Improvements/Applications: Moreover, despite the language barrier, the students were able to improve their communication skills.
\end{abstract}

\section{Index Terms}

English as Second Language, Sociocultural adjustment, Academic

\footnotetext{
Corresponding author : Maricel C. San Diego maricel.sandiego@bulsu.edu.ph

- Manuscript received July 25, 2017.

- Revised August 8, 2017; Accepted September 1, 2017.

- Date of publication September 30, 2017.

(C) The Academic Society of Convergence Science Inc.

2546-1583 @ 2017 IJEMR. Personal use is permitted, but republication/redistribution requires IJEMR permission.
} 


\section{INTRODUCTION}

The Philippines is filled with proficient English teachers as Filipinos perform well in English communication, both in written and verbal. In fact, the Philippines ranked first in the 2013 Business English Index, which evaluates competency of global workers in using English in the workplace, with a rating of 7.95. The score fell in the intermediate category that meant Filipinos 'can take an active role in business discussions and perform relatively difficult tasks.' One of the strong foundations for this is the inclusion of English in the basic and secondary education. But aside from learning it in a classroom setting, there was widespread exposure from English in various forms largely contribute to the fluency of the Filipinos [1]. From street signs and advertisements up to national television programs, all these were communicated in English. The author believes that this is a great reinforcement in learning and mastering the language. Since English is deeply rooted in the Philippine education and culture, Filipinos have the edge to excel more in communicating well in English and become good English teachers.

Moreover, foreign students choose to study in the Philippines because courses are more affordable than in Western and European countries. A 60-hour English class cost $\$ 500$, which is one third of the price of the same class in the US or Canada [2]. The Philippines Daily Inquirer (2011) reported that foreign students prefer to study in the Philippines because of the affordable but high quality education. The local broadsheet noted that a four-year degree program in the Philippines would amount to $\$ 1,000$ 2,500 while in the US a similar program would cost more than $\$ 30,000$.

Not only does the foreign students benefit from studying abroad, the host country also get a fair share of gains from the students. Foreign students play a major role in providing $£ 7$ billion to the UK economy [3]. Aside from contributing additional funds, the organization also noted that foreign students internationalize the campus and its programs and diversify student environment. With the surge of foreign students in the Philippines, it is no doubt that the country also benefit from this occurrence. They bring additional funds for higher educational institutions and provide multicultural exposure for the domestic students. It is truly a winwin situation.

However, foreign students face a lot of dilemma adjusting to the new culture and environment when they choose to study abroad. It is vital for colleges and universities to ensure that foreign students are well-adjusted to the new culture and environment because lack of the former would lead to student dropout [4]. This will also lower foreign student's confidence.

In the Philippines, region III or Central Luzon in particular have various higher educational institutions that offer quality English program for international students. In order to continuously improve the quality of international programs of domestic HEIs, the researcher aimed to determine the sociocultural adjustments of foreign students in the Philippines in terms of behavioral adaptation difficulty and cognitive adaptation difficulty. This will provide further information about the factors that hinder or help their learning experience in the country.

Foreign students usually deal with adjusting to the culture of the host country and may feel invisible during their classes [4]. They are also fazed by the pressure of living independently which make them feel lonely, homesick and isolated from the domestic students. Foreign students face depression due to 'lack of concentration and low motivation' with regards to their academics and social life [4]. Hence, sociocultural adaptation appears to be vital in the overall academic achievement of foreign students. It is influenced by various factors that support 'culture learning and social skills acquisition' [5]. Letting the foreign students feel a sense of belongingness and acceptance from their peers and professors would positively affect their academic stay in the host university.

Aside from the behavioral aspect, cognitive adaptation is also an important factor in determining the sociocultural adaptation of foreign students. Majority of the students who come to the Philippines to study want to learn the English language. The ability to speak a global language may help a person see himself/herself as part of a transnational community of English speakers [6]. Since English has been widely accepted as the medium of communication across various fields, learning it as a foreign language appeals to many non-native English speakers especially in Asian countries.

\section{RESEARCH Model}

The research used quantitative method that deals with analyzation of numerical data by utilizing mathematical processes [5]. This method involves the collection and manipulation of "hard data" to produce the desired results by the research [7].

\section{A. Respondents}

The researcher selected 50 students of Bulacan State University and another 50 students of Ramon Magsaysay Technological University who are enrolled for the past two months in one of their academic programs. Both universities offer 
international programs to cater the rising needs of foreign students.

\section{B. Research Instrument}

The two research instruments used were adopted from Li (2010). The twenty-one item questionnaire was used to ascertain the behavioral adaptation difficulty of the foreign students, while the five-item questionnaire was utilized to determine their cognitive adaptation difficulty.

\section{Conceptual Framework}

Using the Input-Process-Output model, the needed data was gathered through using the questionnaire adopted from $\mathrm{Li}$ (2010). After tabulating the frequency of the gathered data, the information were statistically treated using the Statistical Package for Social Sciences (SPSS). The mean was determined for each statement per questionnaire, which is also the basis for the verbal interpretation for each statement.

\begin{tabular}{|c|c|c|}
\hline Input & Process & Output \\
\hline $\begin{array}{l}\text { Socioc } \\
\text { ultural } \\
\text { Adapta } \\
\text { tion } \\
\text { Questio } \\
\text { nnaire }\end{array}$ & $\begin{array}{l}\text { 1. Response } \\
\text { 2. Gathering } \\
\text { 3. Assessment } \\
\text { 4. Descriptive } \\
\text { Analysis } \\
\text { 5. Quantitative } \\
\text { Analysis and } \\
\text { Corroboration }\end{array}$ & $\begin{array}{l}\text { 1. Assessment of } \\
\text { sociocultural and } \\
\text { cognitive } \\
\text { adaptation } \\
\text { difficulty results } \\
2 . \\
\text { Recommendatio } \\
\text { ns }\end{array}$ \\
\hline
\end{tabular}

Fig. 1. Conceptual Framework

\section{RESEARCH RESULTS}

The following tables show the outcome of the research focusing on the sociocultural adjustment of foreign students in terms of behavioral adaptation difficulty and cognitive adaptation difficulty. Table 1 shows the perceived level of adjustment of foreign students in terms of behavioral adaptation. Table 2 presents the perceived level of adjustment in terms of cognitive adaptation.

Table 1. Perceived LeVEl of Socio-CUltural AdJUSTMENT OF THE FOREIGN STUDENTS IN TERMS OF BEHAVIORAL ADAPTATION DIFFICULTY

\begin{tabular}{cccccccc}
\hline \hline Statement & 5 & 4 & 3 & 2 & 1 & Mean & Int. \\
& Behavioral Adaptation & Difficulty & & \\
\hline
\end{tabular}

\begin{tabular}{|c|c|c|c|c|c|c|c|c|}
\hline 2. & $\begin{array}{l}\text { Finding food that } \\
\text { you enjoy. }\end{array}$ & 0 & 6 & 44 & 18 & 32 & 2.24 & $\mathrm{SD}$ \\
\hline 3. & $\begin{array}{l}\text { Following rules } \\
\text { and regulations. }\end{array}$ & 0 & 6 & 42 & 22 & 30 & 2.24 & $\mathrm{SD}$ \\
\hline 4. & $\begin{array}{l}\text { Dealing with } \\
\text { people with } \\
\text { authority. }\end{array}$ & 0 & 4 & 52 & 16 & 28 & 2.32 & $\mathrm{SD}$ \\
\hline 5. & $\begin{array}{l}\text { Using the } \\
\text { transport system. }\end{array}$ & 0 & 6 & 50 & 22 & 22 & 2.40 & $\mathrm{SD}$ \\
\hline 6. & $\begin{array}{l}\text { Dealing with } \\
\text { bureaucracy. }\end{array}$ & 0 & 6 & 60 & 14 & 20 & 2.52 & $\mathrm{MD}$ \\
\hline 7. & $\begin{array}{l}\text { Making yourself } \\
\text { understood }\end{array}$ & 4 & 0 & 48 & 26 & 22 & 2.38 & $\mathrm{SD}$ \\
\hline 8. & Going shopping. & 2 & 2 & 38 & 14 & 44 & 2.04 & $\mathrm{SD}$ \\
\hline 9. & $\begin{array}{l}\text { Dealing with } \\
\text { someone who is } \\
\text { unpleasant. }\end{array}$ & 0 & 12 & 48 & 16 & 24 & 2.48 & SD \\
\hline 10. & $\begin{array}{l}\text { Understanding } \\
\text { jokes and humor. }\end{array}$ & 2 & 10 & 42 & 18 & 28 & 2.40 & $\mathrm{SD}$ \\
\hline 11. & Accommodation. & 0 & 4 & 48 & 16 & 32 & 2.24 & $\mathrm{SD}$ \\
\hline 12. & $\begin{array}{l}\text { Going to special } \\
\text { gatherings. }\end{array}$ & 0 & 2 & 46 & 18 & 34 & 2.16 & $\mathrm{SD}$ \\
\hline 13. & $\begin{array}{l}\text { Dealing with } \\
\text { people staring at } \\
\text { you. }\end{array}$ & 0 & 8 & 46 & 16 & 30 & 2.32 & $\mathrm{SD}$ \\
\hline 14. & $\begin{array}{l}\text { Dealing with } \\
\text { unsatisfactory } \\
\text { service. }\end{array}$ & 0 & 10 & 50 & 20 & 20 & 2.50 & MD \\
\hline 15. & Worshipping. & 0 & 8 & 48 & 16 & 28 & 2.36 & $\mathrm{SD}$ \\
\hline 16. & $\begin{array}{l}\text { Relating to } \\
\text { members of the } \\
\text { opposite sex. }\end{array}$ & 6 & 2 & 44 & 20 & 28 & 2.38 & $\mathrm{SD}$ \\
\hline 17. & $\begin{array}{l}\text { Finding your } \\
\text { way around. }\end{array}$ & 0 & 4 & 48 & 18 & 30 & 2.26 & $\mathrm{SD}$ \\
\hline 18. & $\begin{array}{l}\text { Talking about } \\
\text { you with others. }\end{array}$ & 0 & 6 & 50 & 14 & 30 & 2.32 & $\mathrm{SD}$ \\
\hline 19. & $\begin{array}{l}\text { Dealing with the } \\
\text { climate. }\end{array}$ & 0 & 4 & 48 & 18 & 30 & 2.26 & $\mathrm{SD}$ \\
\hline 20. & $\begin{array}{l}\text { Family } \\
\text { relationship. }\end{array}$ & 0 & 4 & 44 & 18 & 34 & 2.18 & $\mathrm{SD}$ \\
\hline 21. & The pace of life. & 0 & 10 & 44 & 10 & 36 & 2.28 & $\mathrm{SD}$ \\
\hline
\end{tabular}

As shown in Table 1, the foreign students perceive to have slight difficulty in adjusting to the culture of the host country. They experienced minimal struggle in coping up with their new surroundings and making new relationship with their peers and professors. Out of 21 items, the respondents answered moderate difficulty to only two statements. Overall, this showed that the two local universities provide adequate support to their foreign students that enable them to adjust well to their day to day living.

Table 2. Perceived LeVEl of Socio-CUltural AdJustMent of THE Foreign STUDENTS IN TERMS OF COGNITIVE ADAPTATION DIFFICULTY

\begin{tabular}{lccccccc}
\hline \hline \multicolumn{1}{c}{ Statement } & $\mathbf{5}$ & $\mathbf{4}$ & $\mathbf{3}$ & $\mathbf{2}$ & $\mathbf{1}$ & Mean & Int. \\
\hline \multicolumn{7}{c}{ Cognitive } & Adaptation Difficulty \\
\hline $\begin{array}{l}\text { 1. Understanding } \\
\text { the host country }\end{array}$ & 0 & 6 & 48 & 20 & 26 & 2.34 & SD \\
$\begin{array}{l}\text { value system. } \\
\begin{array}{l}\text { 2. Seeing things } \\
\text { from Philippine's } \\
\text { point of view. }\end{array}\end{array}$ & & 6 & 44 & 28 & 22 & 2.34 & SD \\
\hline \hline
\end{tabular}




\begin{tabular}{llllllll}
\hline \hline $\begin{array}{l}\text { 3. Understanding } \\
\text { ethnic and cultural } \\
\text { differences. }\end{array}$ & 0 & 2 & 50 & 20 & 28 & 2.26 & SD \\
\hline $\begin{array}{l}\text { 4. Understanding } \\
\text { the Philippine's } \\
\text { world view }\end{array}$ & 0 & 4 & 48 & 18 & 30 & 2.26 & SD \\
\hline \hline
\end{tabular}

As presented in Table 2, the foreign students experience slight difficulty in understanding the Philippine culture and traditions. All four items obtained a mean ranging from $2.26-2.34$ that meant a rating of "Slight Difficulty." In a way, it reflected their cognitive ability in communicating in English as they were able to express their queries and understanding about the Filipino culture. Through this, the foreign students from both universities became easily well-accustomed to the way of living of Filipinos.

\section{Conclusion}

Based on the results of the research, the foreign students are well-adjusted in the host country in terms of their behavioral and cognitive adaptation. Majority of statements were met with an interpretation of "slight difficulty," which means that respondents experienced minimal struggle in adapting to the new culture and environment. They also did not experience much problem in making new friends, going to special gatherings and shopping for their needs. This shows that the BulSU and RTMU provide enough resources to cover the needs of the foreign students. They also ensure that the foreign students feel welcomed and treated as a family.

As indicated on the results of the cognitive adaptation of the foreign students, all four statements were also met with an interpretation of "slight difficulty." Both BulSU and RTMU make it a point to explain and guide the students regarding the Filipino traditions and values. In this sense, the foreign students somehow felt a familial connection with the local students and their professors. Because of the hospitability of Filipinos, foreign students do not feel isolated and pressured throughout their academic stay in the country.

The current research only dealt with the 100 foreign students from two local higher educational institutions in the Philippines. Future studies may opt to research on other aspects that affect the learning experience of foreign students.

\section{REFERENCES}

[1] Chavez, A. (2014). What Asia Can Learn From Philippines About English Education. Retrieved November, 16, 2014.

[2] McGeown, K. (2012). The Philippines: The world's budget English teacher. BBC News.
[3] Universities, U. K. (2014). The Funding Environment for Universities 2014. International Students in Higher Education: the UK and its competition. Retrieved from URL: http://www. universitiesuk. ac.

uk/highereducation/Documents/2014/InternationalStudentsIn HigherEducation. pdf.

[4] Zhao, L. (2010). Socio-Cultural Adjustment of International Students as Expatriates in America.

[5] Wilson, G. P. (2011). Fitting-in: Sociocultural adaptation of international graduate students. Johnson \& Wales University.

[6] Crystal, D. (2003). English as a global language. Cambridge: Cambridge University Press

[7] Muijs, D. (2010). Doing quantitative research in education with SPSS. Sage, $1-2$

[8] Neumann, W. L. (1997). Social Research Methods: Qualitative and Quantitative Approaches 3 H@. ed. Allen \& Bacon, United States of America. 